\title{
Mobility of Heavy Metals in Plants and Soil: A Case Study From A Mining Region in Canada
}

\author{
${ }^{1,2}$ Mehes-Smith, M., ${ }^{1,2}$ K.K. Nkongolo, ${ }^{1,2}$ R. Narendrula and ${ }^{3}$ E. Cholewa \\ ${ }^{1}$ Department of Biology, \\ ${ }^{2}$ Biomolecular Sciences Program, \\ Laurentian University, Sudbury, Ontario, Canada \\ ${ }^{3}$ Department of Biology, Nipissing University, North Bay, Ontario, P1B 8L7, Canada
}

Received 2013-12-15; Revised 2013-12-28; Accepted 2014-01-15

\begin{abstract}
Understanding the dynamic of metals in soil and plantsis essential for ecosystem management and risks assessment of environmental pollution and sustainability.The main objective of the present study is to determine the mobility of $\mathrm{Ni}, \mathrm{Cu}, \mathrm{Fe}, \mathrm{Mg}$ and $\mathrm{Zn}$ in soil and their translocation in $D$. cespitosa plants in a mining region in Northern Ontario.The total amount of $\mathrm{Cu}, \mathrm{Ni}, \mathrm{Fe}, \mathrm{Mg}$ and $\mathrm{Zn}$ were significantly higher in the top horizon (LFH) compared to the adjacent layer Ae. The vertical distribution of metals in soil varied with the type of metals. The results of this study indicated that only a small portion of total metal was bioavailable to plants. The enrichment factor values for the targeted elements were far above the value of contamination resulting in high availability and distribution of metals in soil. The average bioconcentration/bioaccumulation factors (metal concentration ratio of plant roots to soil) was high and varied from 3.1 to 40 for $\mathrm{Cu}, 24.5$ to 91.6 for $\mathrm{Fe}$, 18.2 to 398.6 for $\mathrm{Mg}, 10.3$ to 75.5 for $\mathrm{Ni}$ and 24.9 to 73 for $\mathrm{Zn}$. The translocation factor values were very low for the five metals. They ranged from 0.05 to 0.46 for $\mathrm{Cu}, 0.03$ to 0.1 for $\mathrm{Fe}, 0.28$ to 1.48 for $\mathrm{Mg}, 0.15$ to 0.38 for $\mathrm{Ni}$ and 0.68 to 1.16 for $\mathrm{Zn}$. Based on existing classification, Deschampsia. cespitosa is an excluder as it has high levels of metals in the roots but with a shoot/root ratio less than 1 . This plant has a high potential for phytoextraction of metals from Northern Ontario soils.
\end{abstract}

Keywords: Metal Distribution in Soil, Enrichment and Translocation Factors, Deschampsiacespitosa, Northern Ontario

\section{INTRODUCTION}

The effects of metals on the environment should be assessed to minimize the threat of soil and groundwater pollution. Heavy metals are not permanently fixed in soils and their distribution in ecosystems is a key issue in environmental management and protection (De Matos et al., 2001). Some metals are subject to bioaccumulation because of their immobile nature. Other metals are mobile and have potential of transfer either through soil profile down to ground water or through plant-root uptake (Businelli et al., 2009a; 2009b; Kouame et al., 2010). Metal mobility is influenced by soil properties such as organic matter, oxides as well as soil structure and profile development. Soil type, vegetation, hydrology, land use and biological activity play a key role in longterm patterns of metal mobility (De Matos et al., 2001; Businelli et al., 2009b; Lal, 2010; Kouame et al., 2010; Ashraf et al., 2012). The majority of metals are toxic to living organisms at certain concentrations.

The Greater Sudbury Region is highly known for its nickel, copper and other metal deposits. The mining, roasting and smelting of these elements have caused disastrous effects on the vegetation and overall environment (Amiro and Courtin, 1981; Gratton et al., 2000; Nkongolo et al., 2008; Vandeligt et al., 2011; Narendrula et al., 2012; 2013). The effects have caused areas to become semi-barren to completely barren and studies on these outcomes have found sulfur dioxide Corresponding Author: K.K. Nkongolo, Biomolecular Sciences Program, Laurentian University, Sudbury, Ontario, Canada 
emissions and metal particulates in soil to be the source. Concentrations of metal, specifically nickel and copper, have been found to be higher in areas around smelters compared to other regions (Gratton et al., 2000; Nkongolo et al., 2007). The high metal content did increase the levels of soil acidity which affects plant growth.

During the last 30 years, production of nickel, copper and other metals has remained at high levels however, industrial sulphur dioxide emissionhave been reduced by about $90 \%$. This has allowed for a certain degree of recovery to occur (Backor and Fahselt, 2004). This recovery has been sustained by the Sudbury Regreening/Land Reclamation program, which has reached over 9 million trees planted in the Greater Sudbury Region.

Risks assessment of environmental pollution and sustainability has to take into account the mobility and the bioavailability of metals, since plant uptake of metals parallels the bioavailable fractions of the metals in soil (Sherene, 2010). Most studies of Sudbury ecosystems describe only the levels of total metals in soils, but bioavailable concentration of metals in soil may be a better predictor for environmental impact of historical and current emissions of metals (Peijnenburg et al., 1997; Tack and Verloo, 1995; Abedin and Spiers, 2006; Tashakor et al., 2011; Abedin et al., 2012). Assessment of the levels of metal bioavailability and bioaccessibility is critical in understanding the possible effect on soil biota (Ettler et al., 2012; Juhasz et al., 2011). In addition, $\mathrm{Ni}$ and $\mathrm{Cu}$ are two main toxic elements that cause physiological challenges to plant growth in many mining areas in Canada.

A relatively small group of hyperaccumulator plants is capable of sequestering heavy metals in their shoot tissues at high concentrations. Persistent exposure of natural populations to inadequate or toxic micronutrient availability would be expected to provoke evolutionary adaptation. Most of these species are facultative metallophytes; they occur on both normal and metalliferous soil types. We hypothesize that $D$. cespitosa growing in metal contaminated sites in Northern Ontario for over a century might belong to the hyperaccumulator plant group. To date, no study has been conducted to determine the tolerance mechanism and metal allocation of both $\mathrm{Ni}$ and $\mathrm{Cu}$ in D. cespitosa. Tolerance characteristics, metal uptake and compartmentalization are highly variable among plant species. The physiological mechanisms for the tolerance of a metal also vary between metals. The phytotoxic threshold is unknown, as well as the internal toxic effects. Despite recent advances, the mechanism underlying hyperaccumulation is still not welldefined (Yang et al., 2005a; 2005b).
The main objective of the present study is to determine the mobility of metals, mostly $\mathrm{Ni}, \mathrm{Cu}, \mathrm{Fe}$, $\mathrm{Mg}$ and $\mathrm{Zn}$ in soil as well as their translocation in $D$. cespitosaplants found growing in a mining region in Northern Ontario.

\section{MATERIALS AND METHODS}

\subsection{Metal Analysis in Soil and Plant Tissues}

To measure vertical and horizontal mobility of metal in soil, 20 pedons per site were collected and analyzed. These pedons were from stable/non-eroded and disturbed/eroded areas at Daisy Lake, Wahapitae Dam Hydro, Kelly Lake, Laurentian, Kukagami, Kingsway and Capreol sites (Fig. 1). For metal translocation in plants, soil, root, shoot and foliage samples from 12 plants per site were collected in Deschampsiacespitosa populations from wetlands in four sites that include Kelly Lake, Wahnapitae Hill, WahnapitaeHydro Dam and Low Water. The later located over $50 \mathrm{~km}$ from a smelter was used as a reference site. Soil samples were air dried and stored in sealed plastic bags prior to preparation for chemical analysis.

Soil $\mathrm{pH}$ was measured in water and a neutral salt solution $\mathrm{pH}\left(0.1 \mathrm{M} \mathrm{CaCl}_{2}\right)$ (Carter, 2007). The total $\mathrm{Cu}, \mathrm{Fe}$, $\mathrm{Mg}, \mathrm{Ni}$ and $\mathrm{Zn}$ in soil and D. cespitosaplant tissue was determined using the method described in Gavlak et al. (1994). Air-dried pulverized samples were passed through a mesh sieve $(<80 \mathrm{~mm})$ and placed in a microwave vessel. Concentrated nitric acid and hydrochloric acid was added to the samples and the mixture was heated to $90^{\circ} \mathrm{C}$ for $8 \mathrm{~h}$ in order for complete digestion to occur. The samples containing suspended particulates were then centrifuged (or filtered).

The extractable fraction of $\mathrm{Cu}, \mathrm{Fe}, \mathrm{Mg}$ and $\mathrm{Zn}$ in soil was also done following the method described by Gavlak et al. (1994). Pulverized air dried soil samples were passed through a mesh sieve $(<2.0 \mathrm{~mm})$ and added to Erlenmeyer flasks, to which Mehlich III extracting solution was added. The extraction flasks were then placed on a reciprocating mechanical shaker for five minutes. The mixtures were then filtered and if cloudy, the solution was refiltered.

The extractable Ni in soil was determined using the method described in Gavlak et al. (1994). Pulverized air dried samples were passed through a mesh sieve $(<2.0$ $\mathrm{mm}$ ) and added to extraction vessels. The DTPA extraction reagent was then added and the extraction vessels were placed in a reciprocating mechanical shaker for $2 \mathrm{~h}$ at $25^{\circ} \mathrm{C}$. 


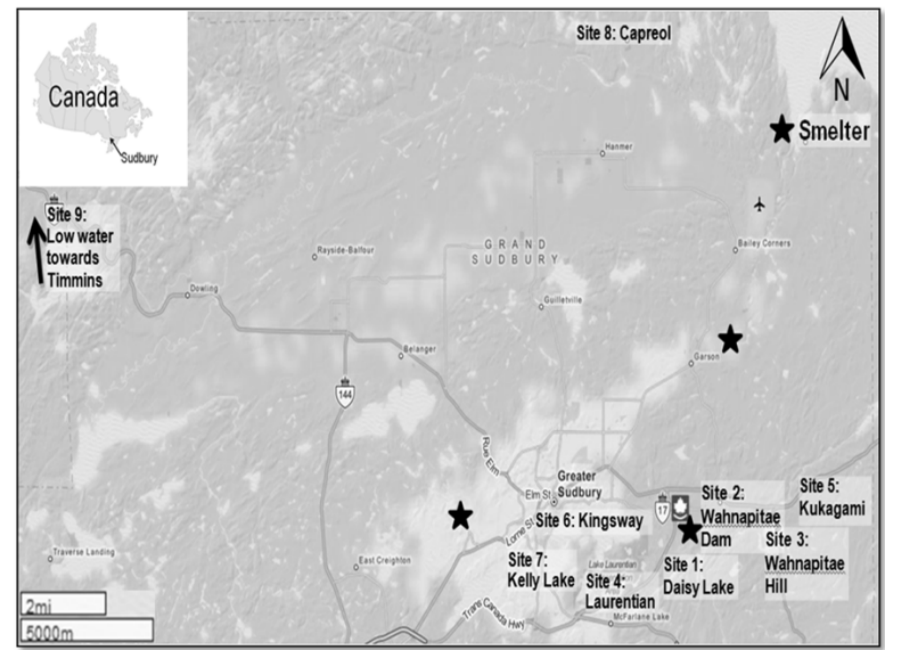

Fig. 1. Map of Northern Ontario showing Deschampsiacespitosa sampling sites (site 1: Daisy Lake; site 2: WahnapitaeHydro Dam; site 3: Wahnapitae Hill; site 4: Laurentian; site 5: Kukagami; site 6: Kingsway; site 7: Kelly Lake; site 8: Capreol; site 9: Low Water Lake)

The detection of total and bioavailable $\mathrm{Cu}, \mathrm{Fe}, \mathrm{Mg}$, $\mathrm{Ni}$ and $\mathrm{Zn}$ of soil digests was determined using Inductively Coupled Plasma Atomic Emission Spectrometry (ICP-AES). The quality control program completed in an ISO 17025 accredited facility The Forest Resources and Soil Testing (FoReST) Laboratory, Faculty of Natural Resources Management Lakehead University Center for Analytical Services (LUCAS), Thunder Bay, Ontario, Canada, included analysis of duplicates, Certified Reference Materials (CRM's), Internal Reference Materials (IRM's), procedural and calibration blanks, with continuous calibration verification and use of internal standards ( $\mathrm{Sc}, \mathrm{Y}, \mathrm{Bi})$ to correct for any mass bias. All concentrations were calculated in mass/mass dry soil basis. The data obtained for all elements of interest in analyzed CRM soil samples were within $\pm 12 \%$ of the certified level.

The enrichment factor was estimated according to equation described by Singh et al. (2010) based on the ratio of metal concentration in soil from contaminated sites to uncontaminated sites. The bioaccumulation/bioconcentration factor was calculated as the ratio of metal concentration in roots over the bioavailable metal in soil. The translocation factor was the ratio of metal concentration in leaves over the metal content in roots.

\subsection{Statistical Analysis}

Since the data were not normally distributed, as assessed by Shapiro-Wilks test $(p>0.05)$ and the homogeneity of variances was violated, as assessed by Levene's Test for Equality of Variances $(p<0.05)$ the non-parametric KruskalWallis test was conducted to compare the metal concentration in soil and various plant parts (roots, shoot and foliage). This was followed by Tukey's HSD multiple comparison analysis, to determine significant differences $(\mathrm{p}<0.05)$ among means.

\section{RESULTS AND DISCUSSION}

\subsection{Metal Mobility in Soil}

Total metal concentrations by horizons are summarized in Table 1 and Fig. 2. The highest total metal concentrations were found in the organic-rich upper soil Horizons (LFH), indicating air emissions as the dominant source for supply of contaminants (Table 1). In fact, significant differences were observed between individual soil depths for all the elements quantified. The total amount of $\mathrm{Cu}, \mathrm{Ni}, \mathrm{Fe}, \mathrm{Mg}$ and $\mathrm{Zn}$ were significantly higher in the Top Horizon (LFH) compared to the adjacent layer Ae. A decrease of $\mathrm{Cu}$ and $\mathrm{Ni}$, in other lower mineral horizons ( $\mathrm{Bm}, \mathrm{Bc}$ and $\mathrm{C}$ ) was observed (Fig. 2). However the analysis of vertical distribution of $\mathrm{Mg}$ revealed no significant decrease of these elements in lower horizons (Table 1). A significant accumulation of $\mathrm{Fe}$ and $\mathrm{Zn}$ in $\mathrm{Bm}, \mathrm{Bc}$ and $\mathrm{C}$ horizons compared to the Ae layer was documented. This suggests that vertical mobility of $\mathrm{Cu}$ and $\mathrm{Ni}$ in soils may not play a key role in their bioavailability in the impacted soils of the Sudbury Region. 
Mehes-Smith, M. et al. / American Journal of Environmental Science 9 (6): 483-493, 2013

Table 1. Mean total concentrations of elements in selected soil horizons from the Sudbury region unlimed sites impacted by varying degrees by smelter aerosolic fallout (concentrations are in $\mathrm{mg} \mathrm{kg}^{-1}$, dry weight)

\begin{tabular}{llllll}
\hline & $\mathrm{Cu}$ & $\mathrm{Fe}$ & $\mathrm{Mg}$ & $\mathrm{Ni}$ & $\mathrm{Zn}$ \\
\hline $\mathrm{LFH}$ & $990 \mathrm{a} \pm 205$ & $26616 \mathrm{a} \pm 3110$ & $2053 \mathrm{a} \pm 276$ & $1150 \mathrm{a} \pm 280$ & $78.9 \mathrm{a} \pm 9.9$ \\
$\mathrm{AE}$ & $163 \mathrm{~b} \pm 25$ & $13899 \mathrm{~b} \pm 1863$ & $858 \mathrm{~b} \pm 92$ & $93.6 \mathrm{~b} \pm 19$ & $36.8 \mathrm{~b} \pm 6.1$ \\
$\mathrm{BM}$ & $107 \mathrm{~b} \pm 17$ & $21683 \mathrm{a} \pm 1114$ & $1020 \mathrm{~b} \pm 91$ & $74.0 \mathrm{~b} \pm 23$ & $62.9 \mathrm{a} \pm 5.9$ \\
$\mathrm{BC}$ & $70.1 \mathrm{~b} \pm 17$ & $20075 \mathrm{a} \pm 1044$ & $987 \mathrm{~b} \pm 67$ & $66.3 \mathrm{~b} \pm 20$ & $60.8 \mathrm{a} \pm 7.7$ \\
$\mathrm{C}$ & $72.6 \mathrm{~b} \pm 42$ & $23060 \mathrm{a} \pm 5719$ & $968 \mathrm{~b} \pm 51$ & $42.3 \mathrm{~b} \pm 5.2$ & $41.4 \mathrm{ab} \pm 4.5$ \\
\hline
\end{tabular}

Means in columns with a common subscript are not significantly different based on Tukey multiple comparison test (p $\geq 0.05) .7$ sites: Daisy Lake, Wahnapitae Hydro Dam, Kelly Lake, Laurentian, Kukagami, Kingsway and Capreol (control)

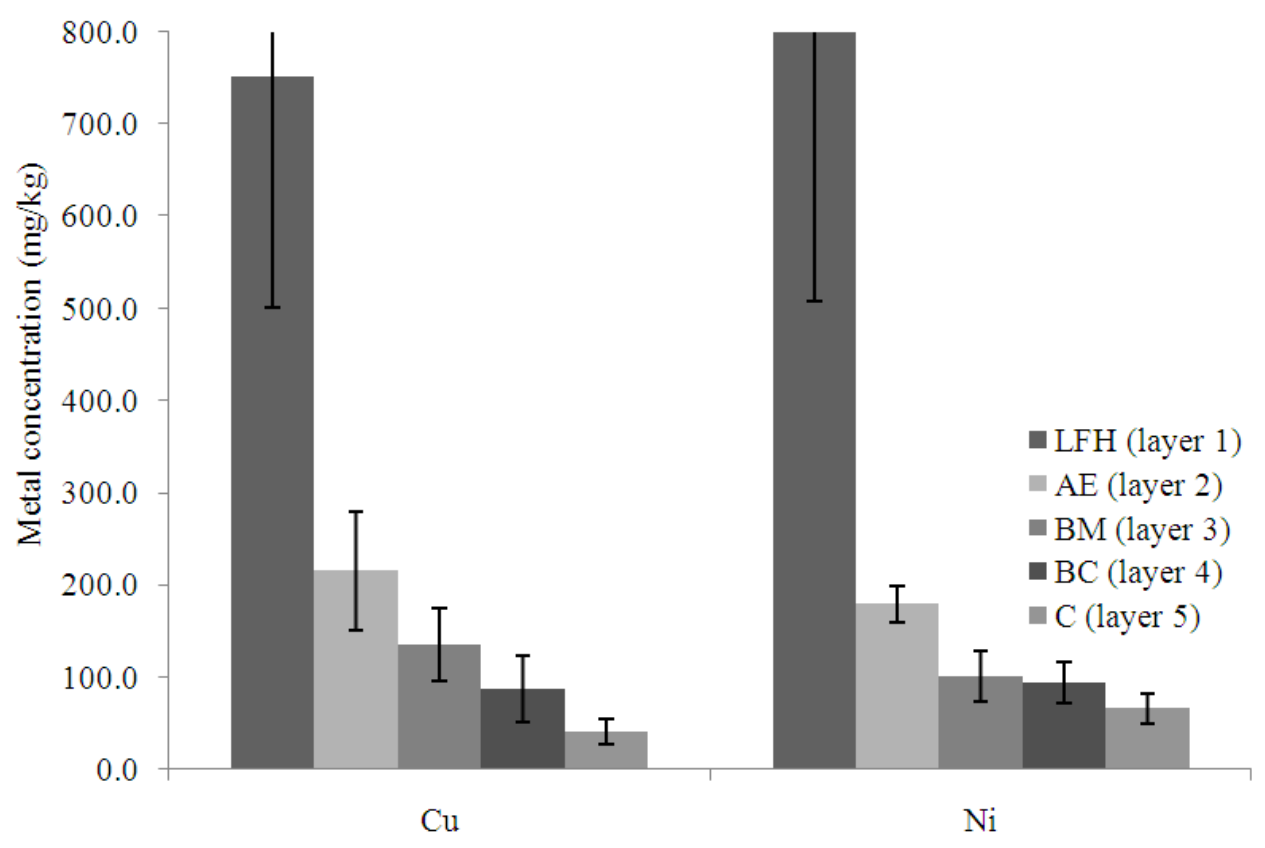

Fig. 2. Metal concentration (mg/kg dry wt) in soil from contaminated and control sites

On the other end, the moderate enrichment of mineral layers in $\mathrm{Fe}, \mathrm{Mg}$ and $\mathrm{Zn}$ may have resulted from the leaching of soluble organo-metal complexes and subsequent adsorption to the lower horizons. This might be related to the proportion of total metal that is bioavailable.

Businelli et al. (2009a; 2009b) also reported a moderate enrichment of the mineral horizons in $\mathrm{Cu}, \mathrm{Zn}$ and $\mathrm{Pb}$ from the top organic layer. Overtime, metal concentrations in mineral horizons generally return to the initial background level suggesting a potential loss of metal from the soil system. The soil is generally considered as a buffering zone that prevents or reduces groundwater and surface water pollution by retardation and dispersion (Madejon et al., 1998; Hellweg et al., 2005; Businelli et al., 2009a; 2009b; Kouame et al., 2010). Several investigations indicated that migration of metals in the soil is very low during the first decades after deposition, compared to the accumulated amount (Madejon et al., 1998; Hellweg et al., 2005; Kouame et al., 2010). The present study suggests that metal loss through soil horizons varied from element to element. In addition, the $\mathrm{pH}$ levels across the sampling sites were below 5, which are not favorable for mesophilic microorganisms' growth and activity that are usually elevated between $20^{\circ} \mathrm{C}$ and $40^{\circ} \mathrm{C}$. There is usually a rapid degradation of the organic matterat highpH. In fact, a low to moderate level of microbiological activity was recorded in our recent survey of the Greater Sudbury forest ecosystem. High concentrations of $\mathrm{Fe}$ might be the results of natural occurrence of this metal in the Sudbury soil that is not related to mining activities. This has been recently documented by Nkongolo et al. (2013).

It was also observed that soil topography plays a key role in metal distribution and horizontal mobility. 
There were no significant differences among sampling sites in a stable and non-eroded areas while a high level of metal content was observed in soil from downhill in a disturbed and eroded sites. This is consistent with (Hellweg et al., 2005; Teixeira et al., 2010; Kouame et al., 2010) who concluded that the behavior of metals is influenced by leachates migration into the soil according to slope of the area and the degree of soil saturation in some metals.

According to Puls et al. (1991), transport of metals may be enhanced due to several factors that include metal association with mobile colloidal size and formation of metal organic and inorganic complexes that do not sorb to soil solid surfaces. Because of the wide range of soil characteristics and various forms by which metals can be added to soil, metal retention by a soil is site specific. Changes in the soil environment overtime, such as the degradation of the organic matter, changes in $\mathrm{pH}$, redox potential, or soil solution composition due to various remediation schemes for instance in the sites targeted in the Greater Sudbury Region may enhance metal mobility.

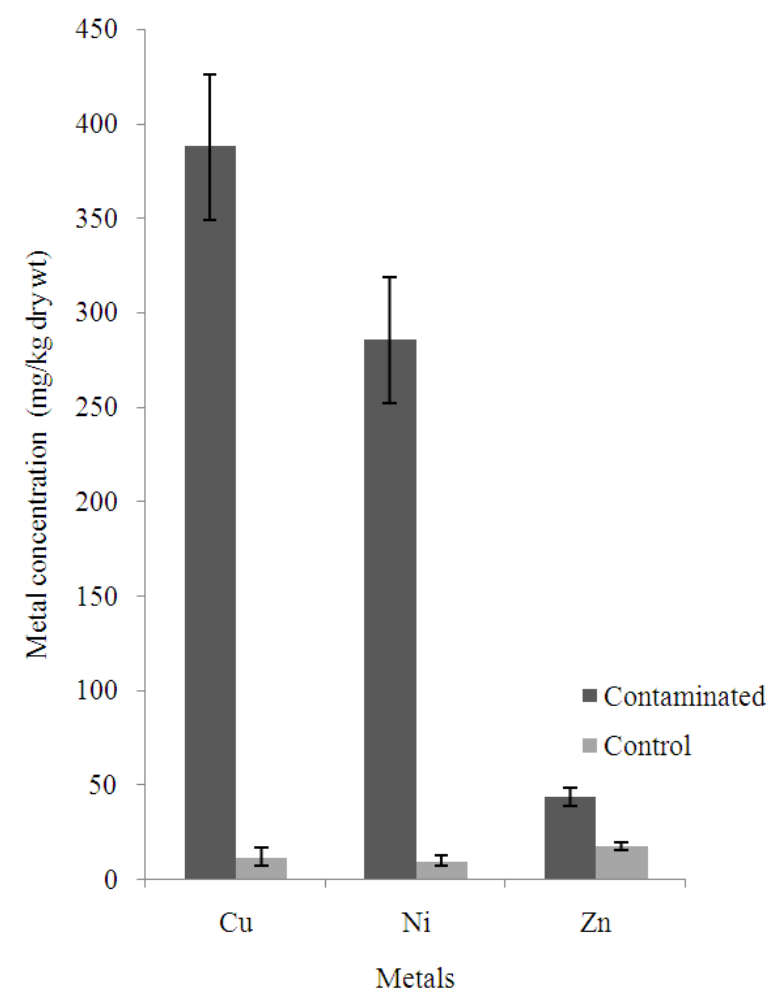

Fig. 3. Total concentration of metals for different layers from sites in Greater Sudbury region. Sites include: Dam, Kelly Lake and Airport
The extent of vertical contamination is related to the soil solution and surface chemistry of the soil matrix with reference to metal. The results from the present study suggested that soil metal contamination in the greater Sudbury Region will not adversely affect ground water quality due to vertical mobility. Considering that most contamination in the ecosystem are from direct aerial deposition, it is expected that aquatic ecosystem within the Greater Sudbury Region is impacted as well by metal contamination from mining activities as documented by Keller et al. (2002).

Figure 3 shows the level of total metal contents in contaminated sites compared to reference areas. Measurement of the total concentration of metals in soils is useful for determining the vertical and horizontal extent of contamination and for measuring any net change (leaching to ground water, surface runoff, erosion) in soil metal concentration overtime. The methods do not however, give an indication as to the chemical form of the metal in the soil system. The totalamount of metals was high in all contaminated sites, but the bioavailable amount was significantly low, suggesting that the level of toxicity to biota is small (Fig. 4). In fact, only $30 \%$ of the total $\mathrm{Cu}$ found in soil around D. cespitosa root system was available to plants. These values were much lower for $\mathrm{Ni}$ and $\mathrm{Zn}$ with only $3 \%$ of total elements that were bioavailable (Fig. 4).

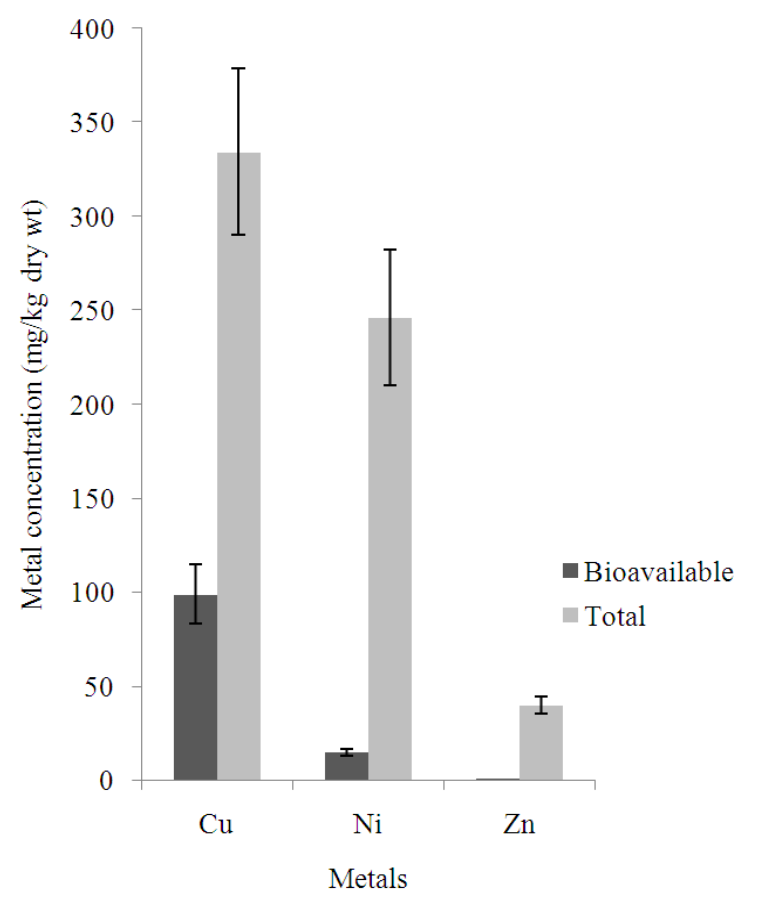

Fig. 4. Bioavailable and total metal concentration ( $\mathrm{mg} / \mathrm{kg}$ dry wt) in soil from the four sampling sites 
The determination of total soil metal content alone is not a good measure of bioavailability and not a very useful tool to quantify contamination and potential environmental and human health risks. Hence, total concentrations of metals in soils are a poor indicator of metal toxicity since metals exist in different solid-phase forms that can vary greatly in terms of their bioavailability (Krishnamurti and Naidu, 2002; 2007; Gobran and Huang, 2005; Violante et al., 2010). In general, the availability of metals for plants depends on soil $\mathrm{pH}$ and on organic matter contents (De Matos et al., 2001). The mobility, bioavailablity and potential toxicity of metal in the soil depend on its concentration in soil solution, the nature of its association with other soluble species and soil ability to release the metal from the solid phase to replenish that removed from soil solution by the plants (Gobran and Huang, 2005; Krishnamurti et al., 2007; Violante et al., 2010). Because the uptake of metals by plants root system is restricted to the liquid phase, the content of particular element in the soil solution is of primary importance. Although an accurate measurement of the level of bioavailable metals in soil creates problems, there are no standardized protocols for estimating the bioavailable metal content in soil. For example, in the present study the extractable $\mathrm{Cu}$, $\mathrm{Fe}, \mathrm{Mg}$ and $\mathrm{Ni}$ were determined using the method described by Gavlak et al. (1994). Recent analysis of the samples from the same sites using the method described by Abedin et al. (2012) resulted in much lower level of bioavailable elements specially for $\mathrm{Cu}$ (Narendrula et al., 2012; Nkongolo et al., 2013). Detailed information about reaction kinetics of the mobilisation and immobilisation process of heavy metals in soil and the importance of mass flow and diffusion for the availability of metals are still needed.

\subsection{Enrichment and Bioaccumulation Factors}

The Enrichment Factor (EF) was calculated for the three main elements $(\mathrm{Cu}, \mathrm{Ni}$ and $\mathrm{Zn})$ produced from mining activities to establish the degree of soil contamination and heavy metal accumulation. It is the ratio between the concentration of metals in contaminated soil and the concentration of metals in uncontaminated soils. Values greater than 1 indicate environmental pollution (Singh et al., 2010). Their respective $\mathrm{EF}$ values were $38.5,34.4$ and 2.7 for $\mathrm{Cu}, \mathrm{Ni}$ and $\mathrm{Zn}$. Figure 3 describes the levels of metals in contaminated and control sites. For the three elements studied, the EF values are far above the value of contamination resulting in high availability and distribution of metals in soil. The high EF values of copper and nickel are attributed to the mining and smelting activities which occurring in the Greater Sudbury Region. These values may be an indication that there may ultimately be an increase in metal accumulation in plants located on contaminated sites.

The Bioconcentration Factor (BCF, metal concentration ratio of plant roots to soil) forDeschampsiacespitosa is very high based on a significantly elevated level of metals in root compared to bioavailable amount in soil (Table 2 and Fig. 5). The average bioconcentration/bioaccumulation factors varied from 3.1 to 40 for $\mathrm{Cu}, 24.5$ to 91.6 for $\mathrm{Fe}, 18.2$ to 398.6 for $\mathrm{Mg}, 10.3$ to 75.5 for $\mathrm{Ni}$ and 24.9 to 73 for $\mathrm{Zn}$ (Table 3). Copper, zinc, iron and magnesium are essentials to plants but can be toxic at high concentration while nickel has no known botanical function.

\subsection{Translocation Factors}

The Translocation Factor (TF) was calculated as the ratio of the concentration of total metal in leaves compared to metal content in roots. In general, The TF values were very low for all the five metals. They ranged from 0.05 to 0.46 for $\mathrm{Cu}, 0.03$ to 0.1 for $\mathrm{Fe}, 0.28$ to 1.48 for $\mathrm{Mg}, 0.15$ to 0.38 for $\mathrm{Ni}$ and 0.68 to 1.16 for $\mathrm{Zn}$ (Table 4).

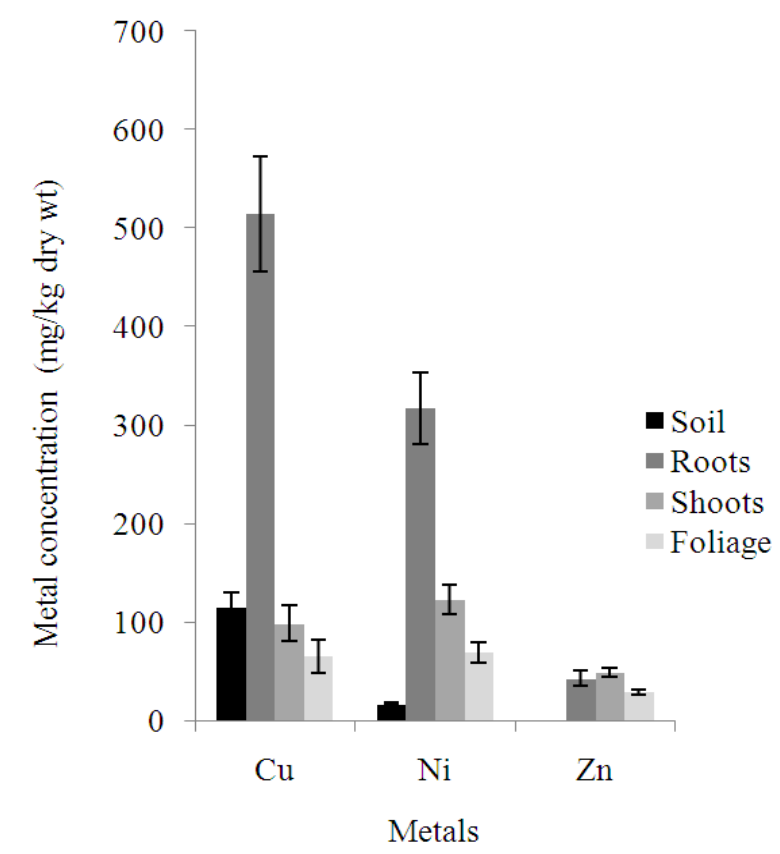

Fig. 5. Metal concentration ( $\mathrm{mg} / \mathrm{kg}$ dry wt) in soil and plant tissue for plants found growing on metal contaminated soil 
Mehes-Smith, M. et al. / American Journal of Environmental Science 9 (6): 483-493, 2013

Table 2. Metal concentration ( $\left.\mathrm{mg} \mathrm{kg}^{-1} \mathrm{dry} \mathrm{wt}\right)$ in soil and plant tissue for plants found growing on metal contaminated soil

\begin{tabular}{|c|c|c|c|c|c|c|}
\hline & & \multicolumn{5}{|l|}{ Element $^{\dagger}$} \\
\hline & & $\mathrm{Cu}$ & $\mathrm{Fe}$ & $\mathrm{Mg}$ & $\mathrm{Ni}$ & $\mathrm{Zn}$ \\
\hline Soil & SEM & $115.25 b \pm 15.07$ & $447.01 \mathrm{~b} \pm 21.42$ & $49.99 c \pm 9.08$ & $17.40 \mathrm{c} \pm 1.6$ & $1.65 \mathrm{c} \pm 0.16$ \\
\hline Roots & SEM & $514.27 \mathrm{a} \pm 58.33$ & $14890.63 \mathrm{a} \pm 1220.27$ & $1785.91 \mathrm{a} \pm 254.36$ & $317.29 \mathrm{a} \pm 36.65$ & $43.40 \mathrm{ab} \pm 8.1$ \\
\hline Shoots & SEM & $99.02 b \pm 18.47$ & $1503.98 \mathrm{~b} \pm 303.71$ & $812.49 b \pm 65.59$ & $123.57 \mathrm{~b} \pm 14.56$ & $49.83 \mathrm{a} \pm 4.45$ \\
\hline Foliage & SEM & $65.78 b \pm 17.03$ & $906.81 \mathrm{~b} \pm 202.06$ & $1036.99 b \pm 105.67$ & $69.59 b c \pm 9.92$ & $29.53 b \pm 2.44$ \\
\hline
\end{tabular}

Metal content in soil represents the bioavailable fraction whereas metal concentration in root, shoot and foliage are the total elements

Table 3. Bioaccumulation factor* of $\mathrm{Cu}, \mathrm{Fe}, \mathrm{Mg}, \mathrm{Ni}$ and $\mathrm{Zn}$ in Deschampsiacespitosa using total and bioavailable elements

\begin{tabular}{|c|c|c|c|c|c|c|}
\hline \multirow[b]{2}{*}{ Sites } & & \multicolumn{5}{|c|}{ Bioavailable elements } \\
\hline & & $\mathrm{Cu}$ & $\mathrm{Fe}$ & $\mathrm{Mg}$ & $\mathrm{Ni}$ & $\mathrm{Zn}$ \\
\hline \multirow[t]{7}{*}{ Wahnapitae hill } & & 4.45 & 44.87 & 47.95 & 15.48 & 18.75 \\
\hline & & 4.74 & 27.69 & 14.02 & 8.93 & 101.70 \\
\hline & & 2.63 & 29.41 & 13.37 & 7.71 & 16.08 \\
\hline & & 1.61 & 9.60 & 12.41 & 8.58 & 27.66 \\
\hline & & 3.25 & 15.98 & 5.92 & 12.09 & 12.56 \\
\hline & & 1.00 & 19.67 & 15.35 & 9.24 & 26.71 \\
\hline & Average SEM & $3.10 \pm 0.53$ & $24.54 \pm 5.06$ & $18.17 \pm 6.10$ & $10.34 \pm 1.19$ & $33.91 \pm 13.77$ \\
\hline \multirow[t]{7}{*}{ Wahnapitae hydro dam } & & 3.85 & 33.27 & 18.19 & 10.74 & 19.53 \\
\hline & & 5.97 & 45.34 & 17.49 & 10.25 & 17.59 \\
\hline & & 11.50 & 50.63 & 93.52 & 20.01 & 56.90 \\
\hline & & 8.13 & 57.60 & 14.72 & 9.57 & 19.68 \\
\hline & & 12.96 & 63.04 & 51.08 & 13.87 & 29.34 \\
\hline & & 5.68 & 26.81 & 25.73 & 11.76 & 25.11 \\
\hline & Average SEM & $8.01 \pm 1.45$ & $46.12 \pm 5.71$ & $36.79 \pm 12.58$ & $12.70 \pm 1.58$ & $28.02 \pm 6.04$ \\
\hline \multirow[t]{7}{*}{ Kelly lake } & & 3.85 & 39.23 & 118.35 & 35.44 & 14.05 \\
\hline & & 3.12 & 43.80 & 815.05 & 49.27 & 37.51 \\
\hline & & 3.26 & 59.94 & 848.21 & 83.01 & 34.09 \\
\hline & & 11.28 & 18.31 & 346.23 & 42.35 & 24.50 \\
\hline & & 4.13 & 23.81 & 82.66 & 37.30 & 11.45 \\
\hline & & 7.22 & 24.34 & 181.59 & 61.40 & 27.70 \\
\hline & Average SEM & $5.48 \pm 1.31$ & $34.91 \pm 6.42$ & $398.68 \pm 141.87$ & $51.46 \pm 7.39$ & $24.88 \pm 4.28$ \\
\hline \multirow[t]{4}{*}{ Low water } & & 38.91 & 38.95 & 118.95 & 48.44 & 123.96 \\
\hline & & 6.62 & 46.90 & 19.84 & 11.26 & 15.81 \\
\hline & & 74.67 & 188.99 & 171.08 & 166.73 & 79.89 \\
\hline & Average SEM & $40.07 \pm 19.65$ & $91.61 \pm 48.74$ & $103.29 \pm 44.36$ & $75.47 \pm 46.87$ & $73.22 \pm 31.40$ \\
\hline
\end{tabular}

Translocation of metals from roots to above ground tissues is a crucial physiological process in an effective utilization of plant to remediate polluted sites (Majid et al., 2012a; 2012b; 2012c; Zacchini et al., 2009; Galfati et al., 2011; Rajoo et al., 2013). Singh et al. (2010) estimated the translocation factor based on total metal in soil only. This approach is not accurate because it underestimates the translocation by considering a large proportion of total metals that are in forms that are not readily available to plants. The assessment of translocation factors based on total metals in roots as described in the present study should provide reliable information on metal movement in plant tissues.

The analysis of plant tissues was important in determining the level of metal uptake and the mobility of elements in D. cespitosa. The low amount of metal in leaves indicate that $D$. cespitosa cope with high levels of metals in soil by sequestrating them in roots, limiting the effects on aerial parts. Based on plant classification described by (Boularbah et al., 2006; Ernst, 2006; Mganga et al., 2011) with reference to metal accumulation, $D$. cespitosa is an excluder as it has high levels of metals in the roots but with shoot/root ratio less than 1 . 
Table 4. Translocation factor* of $\mathrm{Cu}, \mathrm{Fe}, \mathrm{Mg}, \mathrm{Ni}$ and $\mathrm{Zn}$ in Deschampisacespitosa

\begin{tabular}{|c|c|c|c|c|c|c|}
\hline \multirow[b]{2}{*}{ Sites } & & \multirow[b]{2}{*}{$\mathrm{Cu}$} & \multicolumn{4}{|l|}{ Elements } \\
\hline & & & $\mathrm{Fe}$ & $\mathrm{Mg}$ & $\mathrm{Ni}$ & $\mathrm{Zn}$ \\
\hline \multirow[t]{7}{*}{ Wahnapitae hill } & & 0.03 & 0.02 & 0.68 & 0.11 & 1.08 \\
\hline & & 0.05 & 0.03 & 1.31 & 0.18 & 0.25 \\
\hline & & 0.03 & 0.02 & 1.35 & 0.11 & 1.41 \\
\hline & & 0.11 & 0.08 & 1.89 & 0.22 & 0.79 \\
\hline & & 0.05 & 0.03 & 1.75 & 0.15 & 0.74 \\
\hline & & 0.05 & 0.02 & 1.92 & 0.12 & 1.28 \\
\hline & Average SEM & $0.05 \pm 0.01$ & $0.03 \pm 0.01$ & $1.48 \pm 0.19$ & $0.15 \pm 0.02$ & $0.92 \pm 0.17$ \\
\hline \multirow[t]{7}{*}{ Wahnapitae hydro dam } & & 0.09 & 0.14 & 1.15 & 0.22 & 0.79 \\
\hline & & 0.06 & 0.06 & 1.02 & 0.25 & 1.03 \\
\hline & & 0.03 & 0.04 & 0.27 & 0.19 & 0.54 \\
\hline & & 0.06 & 0.09 & 1.02 & 0.33 & 0.81 \\
\hline & & 0.11 & 0.09 & 0.33 & 0.39 & 0.70 \\
\hline & & 0.24 & 0.20 & 0.67 & 0.53 & 0.79 \\
\hline & Average SEM & $0.10 \pm 0.03$ & $0.10 \pm 0.02$ & $0.74 \pm 0.15$ & $0.32 \pm 0.05$ & $0.78 \pm 0.06$ \\
\hline \multirow[t]{7}{*}{ Kelly lake } & & 0.25 & 0.06 & 0.19 & 0.25 & 0.48 \\
\hline & & 0.19 & 0.03 & 0.14 & 0.18 & 0.51 \\
\hline & & 0.15 & 0.02 & 0.15 & 0.14 & 0.53 \\
\hline & & 0.09 & 0.03 & 0.38 & 0.18 & 0.62 \\
\hline & & 0.21 & 0.05 & 0.44 & 0.21 & 1.11 \\
\hline & & 0.23 & 0.07 & 0.37 & 0.25 & 0.83 \\
\hline & Average SEM & $0.19 \pm 0.02$ & $0.04 \pm 0.01$ & $0.28 \pm 0.05$ & $0.20 \pm 0.02$ & $0.68 \pm 0.10$ \\
\hline \multirow[t]{4}{*}{ Low water } & & 0.45 & 0.22 & 0.55 & 0.69 & 1.59 \\
\hline & & 0.18 & 0.06 & 0.43 & 0.20 & 0.79 \\
\hline & & 0.76 & 0.04 & 0.31 & 0.24 & 1.11 \\
\hline & Average SEM & $0.46 \pm 0.17$ & $0.10 \pm 0.06$ & $0.43 \pm 0.07$ & $0.38 \pm 0.16$ & $1.16 \pm 0.23$ \\
\hline
\end{tabular}

* Translocation factor: Metal concentration ratio of plant leaves to roots

To be classified as a hyperaccumulator, a plant has to meet four criteria. They include, shoot/root quotient higher than 1 for metal content, an extraction coefficient higher than 1 , between 10 to 500 times more metals compared in contaminated plants compared to control plants, copper and nickel content in plants higher than $1000 \mathrm{mg} \mathrm{kg}^{-1}$ for copper, nickel and zinc content higher than $10000 \mathrm{mg} \mathrm{kg}^{-1}$ (Fifield and Haines, 2000; Ernst, 2006; Rotkittikhun et al., 2006; Mganga et al., 2011). Other studies revealed that in hard wood species such as red oak growing in the Greater Sudbury Region, the translocation of metals to leaves is significantly higher (Tran et al., 2013). Leavitt et al. (1979) also reported accumulations of $\mathrm{Ag}, \mathrm{Cd}, \mathrm{Cu}$ and $\mathrm{Zn}$ metals in red oak tissue.

Plants with a high Bioconcentration Factor (BCF) and low Translocation Factor (TF) such as D. cespitosa have the potential for phytostabilisation (Galfati et al., 2011; AlTaisan, 2009; Abdu et al., 2011). D. cespitosa might therefore play an important role in phytoextraction of metals from the Sudbury soils and it can contribute to the restoration of forests, since it is able to grow and survive on heavily contaminated soil.

\section{CONCLUSION}

The results of the present study revealed that the highest concentrations of metal and nutrients were observed in the topmost organic layer, LFH. The vertical distribution of metals in soil varied with the type of metals. The proportion of total metals that was bioavailable and readily available to plants was very small. The concentrations of metal in D. cespitosaplant tissue were found to be higher than the bioavailable metals in soil. The average bioconcentration/bioaccumulation factors varied from 3.1 to 40 for $\mathrm{Cu}, 24.5$ to 91.6 for $\mathrm{Fe}, 18.2$ to 398.6 for $\mathrm{Mg}, 10.3$ to 75.5 for $\mathrm{Ni}$ and 24.9 to 73 for $\mathrm{Zn}$. But the translocation of the targeted metals from roots to leaves was very low. Therefore, D. cespitaosa is a metal excluder plant rather than a hyperaccumulator.

\subsection{Future Research Directions, Limitations And Implications}

A detailed study to clearly establish how D. cepitosa plants cope with metal accumulation in soil along with 
physiological and genetic mechanisms involved in tolerance to metal such as copper and nickel is highly recommended. This will contribute significantly to the understanding of $D$. cespitosa metal tolerance. Considering that $D$. cespitosa biomass is small, its impact at large scale for bioremediation is limited. Current studies are focusing on identifying tree species with large biomass and have an extensive root system that can be used in phytoremediation/phytoextraction of metal-contaminated sites of Northern Ontario.

\section{REFERENCES}

Abdu, A., N. Aderis, H. Abdul-Hamid, N.M. Majid and S. Jusop et al., 2011. Using Orthosiphon stamineus B.for phytoremediation of heavy metals in soils amended with sewage sludge. Am. J. Applied Sci., 8: 323-331. DOI: 10.3844/ajassp.2011.323.331

Abedin, J. and G. Spiers, 2006. Metal bioavailability in smelter-impacted land systems. Proceedings of the 3rd Annual Meeting Conference Canadian Land Reclamation Association, (RA' 06), Ottawa, pp: 1-17.

Abedin, J., P. Beckett and G. Spiers, 2012. An evaluation of extractants for assessment of metal phytoavailability to guide reclamation practices in acidic soilscapes in northern regions. Can. J. Soil Sci., 92: 253-268. DOI: 10.4141/cjss2010-061.

Al-Taisan, W.A., 2009. Suitability of using Phragmites australis and Tamarix aphylla as vegetation filters in industrial areas. Am. J. Environ. Sci., 5: 740-747. DOI: 10.3844/ajessp.2009.740.747

Amiro, B.D. and G.M. Courtin, 1981. Patterns of vegetation in the vicinity of an industrially disturbed ecosystem, Sudbury, Ontario. Can. J. Bot., 59: 1623-1639. DOI: 10.1139/b81-221

Ashraf, M.A., M.J. Maah and I. Yusoff, 2012. Chemical speciation and potential mobility of heavy metals in the soil of former tin mining catchment. Sci. World J., 2012: 11-11. DOI: $10.1100 / 2012 / 125608$

Backor, M. and D. Fahselt, 2004. Physiological attributes of the lichen cladonia pleurota in heavy metal-rich and control sites near Sudbury (Ont., Canada). Environ. Exp. Bot., 52: 149-159. DOI: 10.1016/j.envexpbot.2004.01.014

Boularbah, A., C. Schwartz, G. Bitton, W. Aboudrar and A. Ouhammou et al., 2006. Heavy metal contamination from mining sites in South Morocco: 2. Assessment of metal accumulation and toxicity in plants. Chemosphere, 63: 811-817. DOI: 10.1016/j.chemosphere.2005.07.076
Businelli, D., L. Massaccesi and A. Onofri, 2009b. Evaluation of $\mathrm{Pb}$ and ni mobility to groundwater in calcareous urban soils of ancona, Italy. Water Air Soil Pollut., 201: 185-193. DOI: 10.1007/s11270008-9936-0

Businelli, D., L. Massaccesi, D. Said-Pullicino and G. Gigliotti, 2009a. Long-term distribution, mobility and plant availability of compost-derived heavy metals in a landfill covering soil. Sci. Total Environ., 407: 14261435. DOI: $10.1016 /$ j.scitotenv.2008.10.052

Carter, M.R., 2007. Soil Sampling and Methods of Analysis. 2nd Edn., CRC Press, ISBN-10: 1420005278, pp: 1264.

De Matos, A.T., M.P.F. Fontes, L.M. da Costa and M.A. Martinez, 2001. Mobility of heavy metals as related to soil chemical and mineralogical characteristics of brazilian soils. Environ. Pollut., 111: 429-435. DOI: 10.1016/S0269-7491(00)00088-9

Ernst, W.H.O., 2006. Evolution of metal tolerance in higher plants. For. Snow Landsc. Res., 80: 251-274.

Ettler, V., B. Kribek, V. Majer, I. Knesl and M. Mihaljevic, 2012. Differences in the bioaccessibility of metals/metalloids in soils from mining and smelting areas (Copperbelt, Zambia). J. Geochem. Explor., 113: 68-75. DOI: 10.1016/j.gexplo.2011.08.001

Fifield, F.W. and P.J. Haines, 2000. Environmental Analytical Chemistry. 2nd Edn., Wiley-Blackwell, ISBN-10: 0632053836, pp: 490.

Galfati, I., E. Bilal, A.B. Sassi, H. Abdallah and A. Zaier, 2011. Accumulation of heavy metals in native plants growing near the phosphate treatment industry, Tunisia. Carpath. J. Earth Environ., 6: 85-100.

Gavlak, R.G., D.A. Horneck and R.O. Miller, 1994. Plant, Soil and Water Reference Methods for the Western Region. 1st Edn., Western Rural Development Center, Corvallis, pp: 58.

Gobran, G.R. and P.M. Huang, 2005. Biogeochemistry of Trace Elements in the Rhizosphere. 1st Edn., Elsevier Science, ISBN-10: 0444519971, pp: 480.

Gratton, W.S., K.K. Nkongolo and G.A. Spiers, 2000. Heavy metal accumulation in soil and jack pine (pinus banksiana) needles in Sudbury, Ontario, Canada. Bull. Environ. Contam. Toxicol., 64: 550-557. DOI: $10.1007 / \mathrm{s} 001280000038$

Hellweg, S., T.B. Hofstetter and K. Hungerbuhler, 2005. Time-dependent life-cycle assessment of slag landfills with the help of scenario analysis: The example of CD and CU. J. Clean. Prod., 13: 301-320. DOI: 10.1016/j.jclepro.2004.02.016 
Juhasz, A.L., J. Weber and E. Smith, 2011. Impact of soil particle size and bioaccessibility on children and adult lead exposure in peri-urban contaminated soils. J. Hazard. Mater., 186: 1870-1879. DOI: 10.1016/j.jhazmat.2010.12.095

Keller, C., S.P. McGrath and S.J. Dunham, 2002. Trace metal leaching through a soil-grassland system after sewage sludge application. J. Environ. Q., 31: 15501560. DOI: $10.2134 /$ jeq2002.1550

Kouame, I.K., B. Dibi, K. Koffi, I. Savane and I. Sandu, 2010. Statistical approach of assessing horizontal mobility of heavy metals in the soil of akouedo landfill nearby ebrie lagoon (abidjan-cote d'Ivoire). Int. J. Conservat. Sci., 1: 149-160.

Krishnamurti, G.S.R. and R. Naidu, 2002. Solid-solution speciation and phytoavailability of copper and zinc in soils. Environ. Sci. Technol., 36: 2645-2651. DOI: 10.1021/es001601t

Krishnamurti, G.S.R. and R. Naidu, 2007. Chemical Speciation and Bioavailability of Trace Metals. In: Biophysico-Chemical Processes of Heavy Metals and Metalloids in Soil Environments, Violante, A., P.M. Huang and G.M. Gadd (Eds.), John Wiley and Sons, Hoboken, N.J., ISBN-10: 0470175478.

Krishnamurti, G.S.R., M. Pigna, M. Arienzo and A. Violante, 2007. Solid-phase speciation and phytoavailability of copper in representative soils of Italy. Chem. Spec. Bioavailab., 19: 57-67. 10.3184/095422907X211891

Lal, N., 2010. Molecular Mechanisms and Genetic Basis of Heavy Metal Toxicity and Tolerance in Plants. In: Plant Adaptation and Phytoremediation, Ozturk, M.A. and M.S.A. Ahmad (Eds.), Springer, Netherlands, ISBN-10: 9048193702, pp: 35-58.

Leavitt, S.W., R.D. Dueser and H.G. Goodell, 1979. Plant regulation of essential and non-essential heavy metals. J. Applied. Ecol., 16: 203-212. DOI: $10.2307 / 2402739$

Madejon, E., E. Galli and U. Tomati, 1998. Bioremediation of olive mill pomaces for agricultural purposes. Fresenius Environ. Bull., 7: 873-879.

Majid, N.M., M.M. Islam, M.E. Nap, M. Ghafoori and A. Abdu, 2012c. Heavy metal uptake and translocation by Justicia gendarussa burm F. from textile sludge contaminated soil. Acta Agric. Scand., B62: 101-108. DOI: $10.1080 / 09064710.2011 .579994$
Majid, N.M., M.M. Islam, R.A. Rauf, P. Ahmadpour and A. Abdu, 2012a. Assessment of heavy metal uptake and translocation in Dyera costulata for phytoremediation of cadmium contaminated soil. Acta Agric. Scand., 62: 245-250. DOI: 10.1080/09064710.2011.603740

Majid, N.M., M.M. Islam, Y. Riasmi and A. Abdu, 2012b. Assessment of heavy metal uptake and translocation by Pluchea indica L. from sawdust sludge contaminated soil. J. Food Agric. Environ., 10: 849-855.

Mganga, N., M.L.K. Manoko and Z.K. Rulangaranga, 2011. Classification of plants according to their heavy metal content around north mara gold mine, tanzania: Implication for phytoremediation. Tanz. J. Sci., 37: 109-119.

Narendrula, R., K. Nkongolo and P. Beckett, 2012. Comparative soil metal analyses in sudbury (ontario, canada) and lubumbashi (Katanga, DR-Congo). Bull. Environ. Contam. Toxicol., 88: 187-192. DOI: 10.1007/s00128-011-0485-7

Narendrula, R., K.K. Nkongolo, P. Beckett and G. Spiers, 2013. Total and bioavailable metals in two contrasting mining regions (Sudbury in Canada and Lubumbashi in DR-Congo): Relation to genetic variation in plant Populations. Chem. Ecol., 29: 111-127. DOI: 10.1080/02757540.2012.696617

Nkongolo, K.K., A. Vaillancourt, S. Dobrzeniecka, M. Mehes and P. Beckett, 2008. Metal content in soil and black spruce (picea mariana) trees in the sudbury region (Ontario, Canada): Low concentration of arsenic, cadmium and nickel detected near smelter sources. Bull. Environ. Contam. Toxicol., 80: 107-111. DOI: 10.1007/s00128-007-9325-1

Nkongolo, K.K., G. Spiers, P. Beckett, R. Narendrula and G. Theriault et al., 2013. Long-term effects of liming on soil chemistry in stable and eroded upland areas in a mining region. Water Air Soil Pollut., 224: 1-14. DOI: 10.1007/s11270-0131618-X

Nkongolo, K.K., M. Mehes, A. Deck and P. Michael, 2007. Metal content in soil and genetic variation in deschampsiacespitosa populations from northern ontario (Canada): Application of ISSR markers. Eur. J. Genet. Toxicol. 
Peijnenburg, W.J.G.M., L. Posthuma, H.J.P. Eijsackers and H.E. Allen, 1997. A conceptual framework for implementation of bioavailability of metals for environmental management purposes. Ecotoxicol. Environ. Safet., 37: 163-172. DOI: 10.1006/eesa.1997.1539

Puls, R.W., R.M. Powell, D. Clark and C.J. Eldred, 1991. Effects of $\mathrm{pH}$, solid/solution ratio, ionic strength and organic acids on $\mathrm{Pb}$ and $\mathrm{Cd}$ sorption on kaolinite. Water Air Soil Pollut., 57-58: 423-430. DOI: $10.1007 / \mathrm{BF} 00282905$

Rajoo, K.S., A. Abdu, D.K. Singh, H. Abdul-Hamid and S. Jusop et al., 2013. Heavy metal uptake and translocation by Dipterocarpus verrucosus from sewage sludge contaminated soil. Am. J. Environ. Sci., 259-268. 25: DOI: 10.3844/ajessp.2013.259.268

Rotkittikhun, P., M. Kruatrachue, R. Chaiyarat, C. Ngernsansaruay and P. Pokethitiyook et al., 2006. Uptake and accumulation of lead by plants from the bo ngam lead mine area in thailand. Environ. Pollut., 144: 681-688. DOI: 10.1016/j.envpol.2005.12.039

Sherene, T., 2010. Distribution of different fractions of lead at various horizons of contaminated soil pedons of coimbatore district, Tamilnadu. Nat. Environ. Pollut. Technol., 9: 447-452.

Singh, R., D.P. Singh, N. Kumar, S.K. Bhargava and S.C. Barman, 2010. Accumulation and translocation of heavy metals in soil and plants from fly ash contaminated area. J. Environ. Biol., 31: 421-430. PMID: 21186714

Tack, F.M.G. and M.G. Verloo, 1995. Chemical speciation and fractionation in soil and sediment heavy metal analysis: A review. Int. J. Environ. Anal. Chem., 59: 225-238. DOI: 10.1080/03067319508041330

Tashakor, M., W.Z.W. Yaacob and H. Mohamad, 2011. Speciation and availability of $\mathrm{Cr}, \mathrm{Ni}$ and $\mathrm{Co}$ in serpentine soils of ranau, Sabah. Am. J. Geosci., 2: 4-9. DOI: 10.3844 /ajgsp.2011.4.9
Teixeira, R.S., P. Cambier, R.D. Dias, J.P.P. Pinese and A. Jaulin-Soubelet, 2010. Mobility of potentially harmful metals in latosols impacted by the municipal solid waste deposit of londrina. Braz. Applied Geochem., 25: 1-15. DOI: 10.1016/j.apgeochem.2009.09.022

Tran, A., K.K. Nkongolo, M. Mehes-Smith, R. Narendrula and G. Spiers et al., 2013. Effects of liming on soil and plant metal content and distribution: Analysis of Red oak (Quercusrubra) population's diversity in a mining region in Northern Ontario (Canada). Chem. Ecol.

Vandeligt, K.K., K.K. Nkongolo, M. Mehes and P. Beckett, 2011. Genetic analysis of pinus banksiana and pinus resinosa populations from stressed sites contaminated with metals in northern ontario (Canada). Chem. Ecol., 27: 369-380. DOI: 10.1080/02757540.2011.561790

Violante, A., V. Cozzolino, L. Perelomov, A.G. Caporale and M. Pigna, 2010. Mobility and bioavailability of heavy metals and metalloids in soil environments. J. Soil Sci. Plant Nutr., 10: 268-292. DOI: 10.4067/S0718-95162010000100005

Yang, X., Y. Feng, Z.L. He and P.J. Stoffella, 2005b. Molecular mechanisms of heavy metal hyperaccumulation and phytoremediation. J. Trace Elem. Med. Biol., 18: 339-353. DOI: 10.1016/j.jtemb.2005.02.007

Yang, X.E., X.F. Jin, Y. Feng and E. Islam, 2005a. Molecular mechanisms and genetic basis of heavy metal tolerance/hyperaccumulation in Plants. J. Integr. Plant Biol., 47: 1025-1035. DOI: 10.1111/j.1744-7909.2005.00144.x

Zacchini, M., F. Pietrini, G.S. Mugnozza, V. Iori and L. Pietrosanti et al., 2009. Metal tolerance, accumulation and translocation in poplar and willow clones treated with cadmium in hydroponics. Water Air Soil Pollut., 197: 23-34. DOI: 10.1007/s11270008-9788-7 